\title{
The secreted salivary proteome of the pea aphid Acyrthosiphon pisum characterised by mass spectrometry
}

\author{
James C. Carolan ${ }^{1}$, Carol I. J. Fitzroy ${ }^{1}$, Peter D. Ashton ${ }^{2}$, Angela E. Douglas $^{2 *}$ \\ and Thomas L. Wilkinson ${ }^{1}$ \\ ${ }^{1}$ UCD School of Biology and Environmental Science, University College Dublin, Dublin, Ireland \\ ${ }^{2}$ Department of Biology, University of York, York, UK
}

\begin{abstract}
Nine proteins secreted in the saliva of the pea aphid Acyrthosiphon pisum were identified by a proteomics approach using GE-LC-MS/MS and LC-MS/MS, with reference to EST and genomic sequence data for A. pisum. Four proteins were identified by their sequences: a homolog of angiotensin-converting enzyme (an M2 metalloprotease), an M1 zinc-dependant metalloprotease, a glucose-methanol-choline (GMC)-oxidoreductase and a homolog to regucalcin (also known as senescence marker protein 30). The other five proteins are not homologous to any previously described sequence and included an abundant salivary protein (represented by ACYPI009881), with a predicted length of 1161 amino acids and high serine, tyrosine and cysteine content. A. pisum feeds on plant phloem sap and the metalloproteases and regucalcin (a putative calcium-binding protein) are predicted determinants of sustained feeding, by inactivation of plant protein defences and inhibition of calcium-mediated occlusion of phloem sieve elements, respectively. The amino acid composition of ACYPI009881 suggests a role in the aphid salivary sheath that protects the aphid mouthparts from plant defences, and the oxidoreductase may promote gelling of the sheath protein or mediate oxidative detoxification of plant allelochemicals. Further salivary proteins are expected to be identified as more sensitive MS technologies are developed.
\end{abstract}

Received: August 31, 2008 Revised: November 30, 2008 Accepted: December 19, 2008

\section{Keywords:}

Acyrthosiphon pisum / Aphid / LC-MS/MS / Phloem sap / Saliva

\section{Introduction}

Saliva plays a crucial role in the initial processing of food by animals. As well as acting as a lubricant, for example softening dry and tough food, animal saliva can contain bioactive compounds, including enzymes and other proteins, that variously initiate digestion, assist penetration of food and, for

Correspondence: Dr. James C. Carolan, UCD School of Biology and Environmental Science, University College Dublin, Belfield, Dublin 4, Ireland

E-mail: james.carolan@ucd.ie

Fax: +353-1-716-1152 animals feeding on living prey, subdue or circumvent prey defences. The bioactive compounds in blood-feeding animals, such as mosquitoes and ticks, include proteins with anticoagulant, anti-inflammatory and immunosuppressive properties [1-5]. The saliva in plant-feeding insects is predicted to contain an analogous suite of bioactive compounds that modulate, suppress or circumvent plant defences, allowing the insect sufficient time to feed [6-9]. The estimated 500000 plant-feeding insect species include the 'chewing' insects that ingest whole pieces of plant material

* Present address: Department of Entomology, Comstock Hall, Cornell University, Ithaca, NY14850, USA 
and the 'sucking' insects that utilise plant sap (phloem and xylem) and plant cell contents. The continuous production of saliva with components active against plant defences is believed to be particularly important for phloem-feeders because each insect feeds continuously from a single penetration into the plant sieve tubes for hours-to-days.

This study concerns the bioactive protein complement of saliva produced by phloem-feeding aphids. Aphids are major crop pests through both direct damage and as vectors of plant disease, and their saliva is amenable to study because it is secreted copiously when aphids feed on sugar solutions. Two types of aphid saliva are recognized. The gelling saliva is produced prior to sustained feeding from a sieve element. On release into the plant, this saliva solidifies to form a coherent proteinaceous sheath separating the needle-shaped aphid mouthparts (stylets) from the surrounding plant tissue. The watery saliva is secreted into the sieve elements, prior to and during phloem sap ingestion and is reported to contain various enzymes implicated in the suppression of plant defences [9]. Aphids feeding on leguminous plants (peas, beans etc.) are also predicted to have salivary calciumchelating activity that prevents the calcium-dependent plugging of the plant sieve elements [10].

Previous studies of bioactive compounds in aphid saliva have focused principally on bioassays and enzymatic activities of the watery saliva [9], but genomic resources are becoming available for aphids and this is providing new opportunities for research. In particular, EST libraries have been constructed for several species [11, 12], and the full genome of the pea aphid Acyrthosiphon pisum has recently been sequenced and assembled, with the annotation in progress (http://genouest.org/cgi-bin/gbrowse/gbrowse/aphidbase). Furthermore, the essential role of one gene expressed in the salivary glands has been revealed by the premature death of plant-reared pea aphids in which the transcript of this gene was selectively suppressed by RNAi [13]. Genomic data have also been exploited in a proteomic analysis of aphid salivary proteins of the peach-potato aphid Myzus persicae [14], leading to the detection of peptide tags with homology to glucose oxidase, NADH dehydrogenase, $\alpha$-glucosidase and $\alpha$-amylase. Importantly, the pattern of aphid salivary proteins recovered by $1-\mathrm{DE}$ and 2 -DE differs among the several studies of different aphid species [10, 14-17], suggestive of appreciable interspecific variation in the protein complement of aphid saliva. The plant species utilised by aphids vary among species (for example, the pea aphid feeds exclusively on legumes), and the composition of salivary proteins may be an important determinant of the plant range of different aphid species.

The specific purpose of this study was to identify the major proteins in the saliva of the pea aphid A. pisum, exploiting the genomic resources available for protein identification. Saliva was collected from a liquid diet on which the aphids had fed and the purified salivary proteins were analysed by MS, specifically the complementary methods of 1-DE prior to LCMS/MS (GE-LC-MS/MS) and LC-MS/MS.

\section{Materials and methods}

\subsection{Insects}

The routine culture of Acyrthosiphon pisum clone LL01 [18] was maintained on Vicia faba (cv. The Sutton) at $20^{\circ} \mathrm{C}$ with 18L:6D regime. Each collection of saliva used $\sim 4000$ aphids feeding for $24 \mathrm{~h}$ on chemically-defined diet of Douglas et al. [19], held in Parafilm ${ }^{\mathrm{TM}}$ sachets. The diet mix was prepared under aseptic conditions using cell biology grade, endotoxinfree water (Sigma Aldrich, Ireland) filtered through a Filtropur $0.2-\mu \mathrm{m}$ filter (Sarstedt, Ireland). The aphids were administered to the underside of the sachets, where they settled and initiated feeding.

\subsection{Protein collection and concentration}

To obtain the saliva secreted by the aphids into each diet sachet, a hole was pierced in the upper membrane of the diet sachet and the liquid was collected. For each collection, the initial volume of collected diet $(\sim 200 \mathrm{~mL}$, derived from 50 sachets) was brought to $250 \mathrm{~mL}$ with PBS and then concentrated at $4^{\circ} \mathrm{C}$ under nitrogen in a Vivacell 250 Gas Pressure Concentrator (Sartorious Mechatronics, UK) using a 5000 molecular weight cut-off (MWCO) polyethersulfone (PES) membrane. The concentrate $(5 \mathrm{~mL})$ was mixed with $100 \mathrm{~mL}$ PBS and then reduced to $5 \mathrm{~mL}$ as above, followed by centrifugation at $3500 \times \mathrm{g}$ for $50 \mathrm{~min}$ in a Vivaspin 6 (Sartorius Mechatronics UK) with a 3000 MWCO PES membrane. The extract was treated with a 2-D clean-up kit (GE Healthcare, UK), centrifuged and resuspended in either $50 \mathrm{mM}$ ammonium bicarbonate for in-solution digestion or in lysis buffer (9.5 M urea, 2\% CHAPS, 0.8\% Pharmalyte $\mathrm{pH}$ 3-10, $1 \%$ DTT) for gel electrophoresis.

\subsection{Preparative 1-DE}

Two analytical replicates were prepared combining the concentrated saliva from six collections, pooled in a total volume of $30 \mu \mathrm{L}$, added to $15 \mu \mathrm{L} 3 \times$ SDS Blue Loading Buffer (NEB, USA) with $0.01 \mathrm{mM}$ DTT (NEB). Preliminary experiments showed that higher DTT concentrations led to artifactual bands at 66 and $68 \mathrm{kDa}$ when gels were stained with silver nitrate-based stains, leading to the choice of semi-reducing conditions for the fractionation by 1-DE. Proteins were electrophoresed on $12.5 \%$ resolving gels with a $4 \%$ stacking gel, run on the Atto Corporation mini-slab system (MSC, Ireland), and visualised with the PlusOne Silver Staining Kit (GE Healthcare, UK) by a procedure modified from the manufacturer's instructions for compatibility with MS. Gels were digitalised using a GS-800 calibrated densiotometer coupled with the Discovery Series ${ }^{\mathrm{TM}}$ QuantOne software (v 4.4; Bio-Rad, Sweden). 


\subsection{Sample preparation for MS}

Visible protein bands were excised from preparative 1-D gels (see Section 2.3) using sterile scalpel blades and transferred to individual $1.5-\mathrm{mL}$ microfuge tubes with $10 \mu \mathrm{L}$ water to prevent dehydration. Sample preparation used the Ettan ${ }^{\text {TM }}$ Digester (Amersham Biosciences, GE Healthcare) following the manufacturer's instructions for MS-compatible silverstained gels [20]. Briefly, gel slices were destained and washed, reduced with $10 \mathrm{mM}$ DTT in $100 \mathrm{mM}$ ammonium bicarbonate at $56^{\circ} \mathrm{C}$ for $60 \mathrm{~min}$, and then subjected to amidation in $50 \mathrm{mM}$, iodoacetamide (IAA) in $100 \mathrm{mM}$ ammonium bicarbonate at room temperature in the dark for $30 \mathrm{~min}$. Samples were incubated in three 15-min changes of $50 \mathrm{mM}$ ammonium bicarbonate in $50 \% \mathrm{v} / \mathrm{v}$ methanol $37^{\circ} \mathrm{C}$, before addition of $50 \mu \mathrm{L} 70 \% \mathrm{v} / \mathrm{v}$ ACN and incubation for $15 \mathrm{~min}$ at $37^{\circ} \mathrm{C}$. Remaining liquid was removed and the samples were digested overnight with $4 \mathrm{ng} / \mu \mathrm{L}$ sequencinggrade, modified porcine trypsin (Promega, USA) in $50 \mathrm{mM}$ ammonium bicarbonate. The supernatant was transferred to a $0.5-\mathrm{mL}$ microfuge tube and peptides were extracted in $30 \%$ ACN/0.2\% TFA (Sigma-Aldrich, Germany) and then 60\% ACN/0.2\% TFA. Samples were dried under vacuum in an Eppendorf Concentrator 5301 (Sigma-Aldrich) and pellets were resuspended in $12 \mu \mathrm{L} 0.1 \%$ formic acid.

The protein samples from four collections used for insolution digestion (see Section 2.3) were reduced with $200 \mathrm{mM}$ DTT for $45 \mathrm{~min}$ followed by alkylation with $1 \mathrm{M}$ IAA in $100 \mathrm{mM}$ ammonium bicarbonate for $1 \mathrm{~h}$. Alkylation was stopped by adding $20 \mu \mathrm{L} 200 \mathrm{mM}$ DTT and incubating for $45 \mathrm{~min}$. Samples were then digested in $20 \mathrm{ng} / \mu \mathrm{L}$ sequencing-grade, modified porcine trypsin (Promega) at $37^{\circ} \mathrm{C}$ overnight.

\subsection{MS and database searches}

The 1-DE separated proteins were subjected to LC MS/MS on a Finnigan LTQ mass spectrometer (Thermo Fisher Scientific, UK) connected to a Surveyor chromatography system incorporating an auto-sampler. Tryptic peptides resuspended in $12 \mu \mathrm{L} 0.1 \%$ formic acid were purified using a Michrom Peptide C8 CapTrap trapping cartridge (Michrom BioResources, CA). Peptides were eluted off the trap and separated using a Biobasic C18 Picofrit column (New Objective, $\mathrm{MA}$ ) at a flow rate of $100 \mathrm{~nL} / \mathrm{min}$ and gradient of $3-40 \%$ ACN over $40 \mathrm{~min}$.

All data were acquired with the mass spectrometer operating in automatic data-dependent switching mode. A zoom scan was performed on the five most intense ions to determine charge state prior to MS/MS analysis. Protein identification from the MS/MS data was performed using the TurboSEQUEST [21] algorithm in BioWorks v. 3.2 (Thermo Fisher Scientific) to correlate the data against NCBI non-redundant database, the A. pisum genome assembly (http://www.hgsc.bcm.tmc.edu/projects/aphid) and an A. pisum EST database (http://www.aphidests.org/).
The genomic sequence and databases used for peptide/ protein searches were produced and made available by the Human Genome Sequencing Centre at Baylor College of Medicine (www.hgsc.bcm.tmc.edu/) and the International Aphid Genomics Consortium (IAGC). At the time of analysis (August 2008), the genome assembly comprised 22798 scaffolds, and the EST database held 167706 ESTs (from NCBI dbEST) clustered with CAP3 [22] into contigs, which were given systematic 5-digit ID with a prefix of APG. The following search parameters were used: precursor-ion mass tolerance of 1.5 Da, fragment ion tolerance of 1.0 Da with methionine oxidation and cysteine carboxyamidomethylation specified as differential modifications and a maximum of two missed cleavage sites allowed. Two filters were applied: XCorr vs. charge state $(1,2$, and $3=$ $1.90,2.00$, and 2.50 , respectively) and peptide probability ( $p$ $<0.001)$.

\subsection{Protein identification and description}

Peptides obtained from tryptic-digested bands were matched to peptide tags originating from the EST database or a specific genome scaffold. Matches with multiple unique peptides and a cumulative XCorr $>20$ are reported. Single-peptide matches are reported when they are present in more than one 1-DE band or sample type. Amino acid sequences were obtained directly from EST hits using the ExPASy Translate tool (http://us.expasy.org/tools/dna.html) or from predicted ORF from regions of the individual scaffolds containing identified peptides. For genomic sequences with no EST match, ORF and putative intron/exon boundaries were determined using GENSCAN [23; http://genes.mit.edu/ GENSCAN.html] using the default settings. All tags identified from the EST database search and the full EST cluster sequences were TBLASTN searched against the "Acyrthosiphon pisum liner genome scaffolds" using BLASTN on AphidBase (http://www.aphidbase.com/blast/blast.html) to obtain EST and genomic scaffold matches. Intron/exon boundaries and ORF were determined by comparative alignment of entire scaffolds and matched individual EST cluster contiguous sequence using BioEdit v7.0.9 (Hall, T. A., 1999, BioEdit: a user-friendly biological sequence alignment editor and analysis. http://www.mbio.ncsu.edu/BioEdit/ bioedit.html). Reference sequence (Ref Seq) predictions were obtained by conducting BLASTN searches of matched EST or genomic sequences against the NCBI Gene Prediction Ref Seq database using the BLAST search facility on AphidBase (see above). Where available, AphidBase identifiers (beginning with ACYPI) for each of the matched proteins have been reported. With the predicted ORF obtained in these various ways, TBLASTN and BLASTX searches were conducted against the NCBI non-redundant database. Domain and functional motif searches of all translated amino acid sequences were performed using InterProScan (http:// www.ebi.ac.uk/Tools/InterProScan/). 


\section{Results}

\subsection{Preparative 1-DE}

The proteins extracted from the saliva of pea aphids and examined by $1-\mathrm{DE}$ under semi-native conditions consistently included bands at 156, 148, 116, 110, 66, 53 and $43 \mathrm{kDa}$ (Fig. 1). Additional bands were detected in some samples but their sizes were not consistent and they were attributed to variable sample degradation; they were not investigated further.

\subsection{LC-MS/MS and database searches}

TurboSEQUEST search results of the LC-MS/MS data obtained from the in-solution and in-gel samples yielded significant peptide tag matches $(p<0.001)$ to translation products of both A. pisum EST contigs (Table 1; Supporting Information File 1) and genomic sequences (Table 2; Supporting Information File 2). However, searches against the NCBI nr database yielded no well-supported matches to deposited proteins.

In total, 60 unique peptide tags matching 10 EST clusters were obtained from the in-gel and in-solution samples. Most of the EST cluster matches were common to both sample types, although some tags were found in only one or the other sample (Table 1). This difference can be attributed to the relative difference in quantity of each ionised peptide in their respective sample. EST database searches of the MS/MS data indicated that the most frequently obtained tags within aphid saliva matched to EST cluster APG02147 (29 unique tryptic tags in total). These tags were most prevalent in the 1 -
DE 156-kDa band (Fig. 1). Other matched EST clusters present in both sample types include APG09617 (6 tags), APG09831 (5 tags), APG28784 (3 tags), APG10010 (2 tags), and APG01291 (2 tags). Peptide tags matching to EST clusters APG11079 (4 tags), APG01142 (3 tags) and APG10189 (2 tags) were only identified from the in solution sample and APG08296 (4 tags) was only detected in the in-gel sample, specifically at $148 \mathrm{kDa}$ (Fig. 1).

Seventy well-supported peptides matching 12 scaffolds were identified after searches against the genomic database, 10 of which were detected in both the in-solution and in-gel samples (Table 2), and one was exclusive to each of the two sample types (5 peptide tags from the in-solution sample matching to scaffold 2506, and 2 peptide tags in the $53-\mathrm{kDa}$ band of Fig. 1 matching to scaffold 13 504). Many of the proteins that were detected as single peptides in the in-solution sample yielded multiple unique peptides in the in-gel sample.

\subsection{Characterisation of salivary proteins}

\subsubsection{Identified proteins}

Bioinformatic analysis of the matched ESTs and genomic regions yielded four protein identities in the salivary subproteome: two metalloproteases, an oxidoreductase and a member of the senescence marker protein 30/gluconolaconase/luciferine-regenerating enzyme (SGL) family.

Six peptides matching to APG09617/Scaffold 11704 were identified in both the in-solution and in-gel samples and these matched to the Ref Seq XM001951605 (ACYPI000733). TBLASTN search results of the GENSCAN

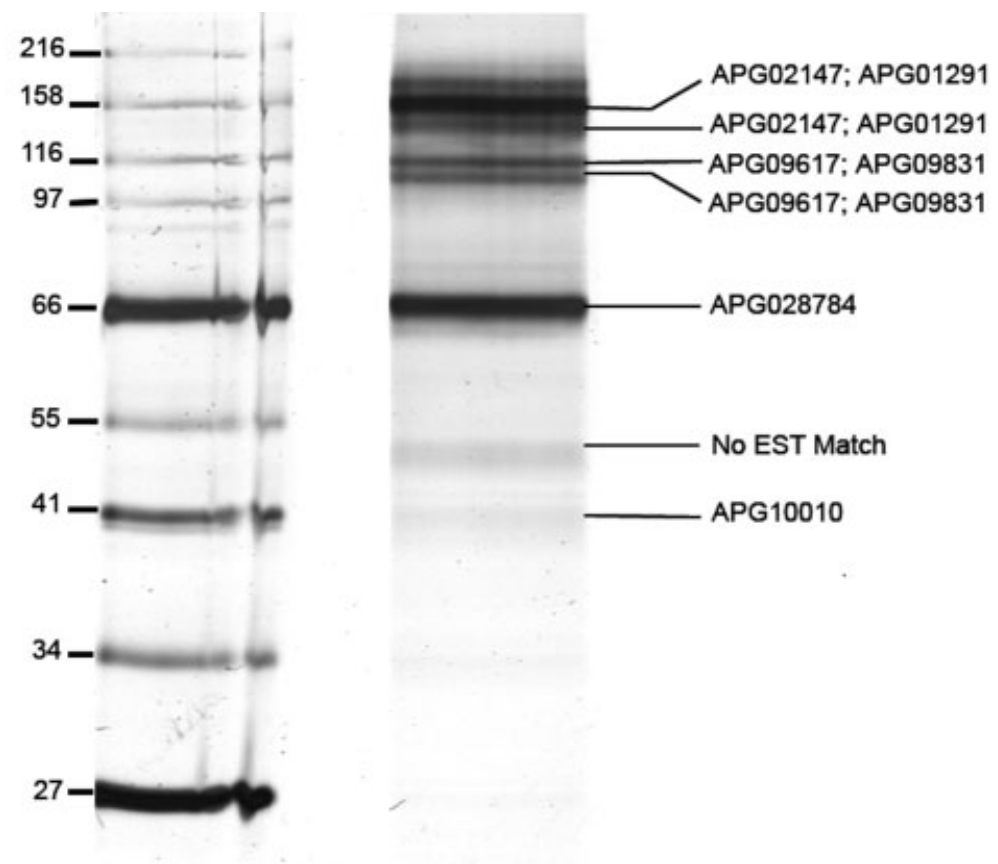

Figure 1. Silver-stained preparative 1-DE gel indicating the bands from which proteins were purified and subjected to LC-MS/MS. Lane 1: Broad Range protein marker (NEB). Lane 2: Fractionated salivary proteins collected from ca. 14000 aphids. Matched ESTs obtained from each excised band are given. 
Table 1. Identified peptides and corresponding ESTs obtained after searches against the aphid EST library

\begin{tabular}{|c|c|c|c|c|c|c|c|c|}
\hline \multirow{2}{*}{$\begin{array}{l}\text { EST } \\
\text { cluster } \\
\text { APG02147 }\end{array}$} & \multirow{2}{*}{$\begin{array}{l}\text { In-sol. } \\
p \text { (pro) } \\
\text { 7.8E-15 }\end{array}$} & \multirow{2}{*}{$\begin{array}{l}\text { In-sol. } \\
\text { score } \\
\text { XC }\end{array}$} & \multirow{2}{*}{$\begin{array}{l}\text { In-gel } \\
p \text { (pro) }\end{array}$} & \multirow{2}{*}{$\begin{array}{l}\text { In-gel } \\
\text { score } \\
\text { XC }\end{array}$} & \multirow{2}{*}{$\begin{array}{l}\begin{array}{l}1-\mathrm{DE}^{\mathrm{c})} \\
\text { band/s }\end{array} \\
156 / 148\end{array}$} & \multicolumn{2}{|c|}{ Sequences of identified peptides } & $\begin{array}{l}\begin{array}{l}\text { EST } \\
\text { coverage } \\
(\%)\end{array} \\
25.8\end{array}$ \\
\hline & & & & & & 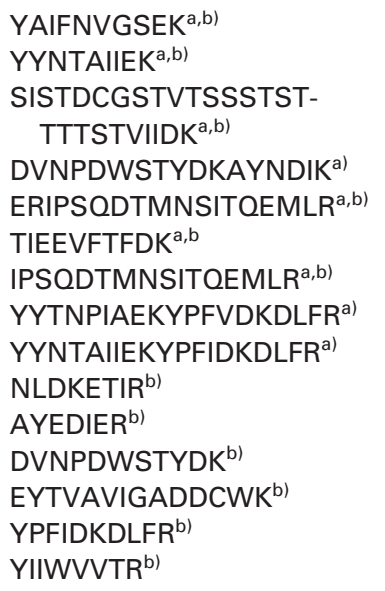 & 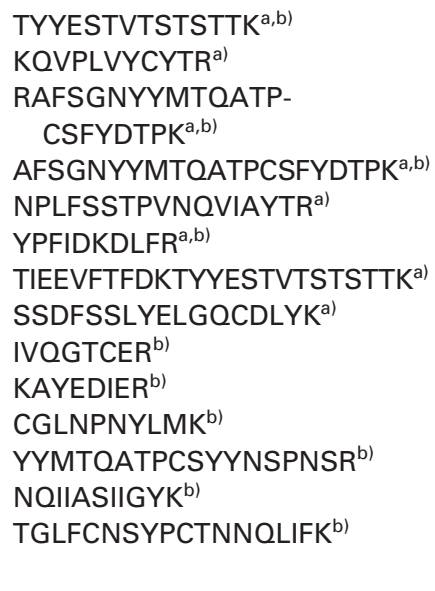 & 25.8 \\
\hline APG09617 & $1.7 \mathrm{E}-09$ & 40.2 & $5.8 \mathrm{E}-08$ & 50.2 & $110 / 116$ & $\begin{array}{l}\text { TEEDFDPGSK }^{\mathrm{a}, \mathrm{b})} \\
\text { TGEYIGWETNKKVCLK }^{\mathrm{a})} \\
\text { GITTEDOYNCDWWK }^{\mathrm{a}, \mathrm{b})}\end{array}$ & $\begin{array}{l}\text { TGEYIGWETNKK }^{\mathrm{a}, \mathrm{b})} \\
\text { TEEDFDPGSKFHIVADVPYIR }^{\mathrm{a})} \\
\text { FHIVADVPYIR }^{\mathrm{b})}\end{array}$ & 28.5 \\
\hline APG09831 & 4.3E-09 & 30.3 & $1.4 \mathrm{E}-09$ & 50.3 & $110 / 116$ & $\begin{array}{l}\text { KLAISLEYSK } \\
\text { LAISLEYSK }^{\mathrm{a}, \mathrm{b})} \\
\text { LEETIDAMOSLYDK }^{\mathrm{b})}\end{array}$ & $\begin{array}{l}\text { YPWTTYKDPNIK }{ }^{\mathrm{a}, \mathrm{b})} \\
\text { KLEETIDAMOSLYDK }^{\mathrm{a}, \mathrm{b})}\end{array}$ & 16.4 \\
\hline APG11079 & $2.7 \mathrm{E}-10$ & 48.3 & - & - & - & $\begin{array}{l}\text { VDYSAVER } \\
\text { YIWATNEFEPTVNY- } \\
\text { OTADPQK } \\
\text { O) }\end{array}$ & $\begin{array}{l}\text { EYFAGKVDYSAVER } \\
\text { VKASLYDLGEI- } \\
\quad \text { GMNLMDDSOTLNDMOR }^{\text {a) }}\end{array}$ & 39.2 \\
\hline APG08296 & - & - & 4.1E-05 & 30.2 & 148 & $\begin{array}{l}\text { FITLNEAGFLVAK } \\
\text { (SDIYEYYOR }^{\text {b) }}\end{array}$ & $\begin{array}{l}\text { YLNWSLDESIIPK } \\
\text { NIEWTAK }^{\text {b) }}\end{array}$ & 32.2 \\
\hline APG28784 & $3.0 \mathrm{E}-6$ & 10.2 & 4.7E-06 & 30.2 & 66 & $\begin{array}{l}\text { SKDPLASPK }^{\mathrm{b})} \\
\text { NRPIEDIVAESQK } \\
\text { a,b) }\end{array}$ & SVGYAMSDSTTR $^{\text {b) }}$ & 8.3 \\
\hline APG01142 & $1.1 \mathrm{E}-09$ & 30.3 & - & - & - & $\begin{array}{l}\text { SVYNYHTLYK } \\
\text { SVYTLNQALANIIAAAR }\end{array}$ & ALLEYSNNSPVITVDDDIPIDR ${ }^{a)}$ & 33.5 \\
\hline APG10010 & 4.7E-8 & 10.2 & 3.0E-09 & 20.2 & 43 & LIDETPGNR $^{\text {b) }}$ & VTNTGSTGFEGVSAK ${ }^{\mathrm{a}, \mathrm{b})}$ & 8.2 \\
\hline APG01291 & $2.4 \mathrm{E}-05$ & 30.2 & $2.6 \mathrm{E}-06$ & 50.2 & 156 & AFPCFDEPEYK ${ }^{\mathrm{a}, \mathrm{b})}$ & KGLTSISNMK $^{\mathrm{a}, \mathrm{b})}$ & 7.6 \\
\hline APG10189 & $9.7 \mathrm{E}-06$ & 18.2 & - & - & - & YPWTTYKNPNIKR ${ }^{a)}$ & LMSVLGTDALPEDK $^{\mathrm{a})}$ & 10.5 \\
\hline
\end{tabular}

a) Peptide tags identified from in-solution sample.

b) Peptide tags identified from in-gel sample.

c) The 1-DE fraction/s comprising the highest abundance of peptide tags for a matched EST cluster.

predicted peptide sequences indicated homology to angiotensin-converting enzyme (ACE: EC 3.4.15.1), an M2 metalloprotease found in insect species such as Locusta migratoria (AY487174), Spodoptera littoralis (EU170161), Tribolium castaneum (XR043079) and Apis mellifera (XM393561). InterProScan searches located motifs for angiotensin-converting enzyme (PANTHER signature: PTHR10514). The EST clusters APG09831 and APG10189 and the GENSCAN output for scaffold 5522 matched to XM001944530 (ACYPI008911), which also indicated homology to ACE in other insect species. InterProScans of these sequences identified ACE motifs (IPR001548) in addition to a signal peptide sequence in the APG10189 cluster (residues 1-84).
A set of matched ESTs and scaffolds indicated homology to M1 zinc metalloproteases. Two peptides matching to EST cluster APG01291 with corresponding matches to genomic sequence along scaffold 10164 (matching XM001950011; ACYPI009427), and 17 peptides matching to genomic sequence along scaffold 128 (matching XM001948813; ACYPI010198) were identified in both the in-gel and in-solution samples. Four peptides matching to EST cluster APG08296 (XM001942782; ACYPI007868) were identified form the in-gel digested sample obtained from the $148-\mathrm{kDa}$ band. Three of the five peptides that were matched to scaffold 2546 were located in close proximity to each other along the genomic scaffold. BLAST search results of the GENSCAN 
Table 2. Identified peptides and corresponding genomic scaffolds and NCBI scaffold accessions obtained after searches against aphid genomic database

\begin{tabular}{|c|c|c|c|c|c|c|c|c|}
\hline \multirow{2}{*}{$\begin{array}{c}\begin{array}{c}\text { Genomic } \\
\text { scaffold }\end{array} \\
128\end{array}$} & \multirow{3}{*}{$\begin{array}{l}\text { NCBI } \\
\text { scaffold }\end{array}$} & \multirow{2}{*}{$\begin{array}{l}\text { In-sol. } \\
p \text { (pro) } \\
4.9 \mathrm{E}-12\end{array}$} & \multirow{2}{*}{$\begin{array}{l}\text { In-sol. } \\
\text { score } \\
\text { XC }\end{array}$} & \multirow{3}{*}{$\begin{array}{l}\text { In-gel } \\
p \text { (pro) }\end{array}$} & \multirow{2}{*}{$\begin{array}{l}\text { In-gel } \\
\text { score } \\
\text { XC } \\
236.3\end{array}$} & \multirow{2}{*}{$\begin{array}{l}\text { 1-DE }{ }^{\mathrm{c})} \\
\text { band/s } \\
156 / 148\end{array}$} & \multicolumn{2}{|c|}{ Sequences of identified peptides } \\
\hline & & & & & & & KGLTSISNMK ${ }^{\mathrm{a}, \mathrm{b})}$ & YYEDYFDEKFPLHK ${ }^{\mathrm{a}, \mathrm{b})}$ \\
\hline & & & & & & & GPILLHMMNTFLGENTFK ${ }^{\mathrm{a}, \mathrm{b})}$ & WLAVTYFEPLGAR ${ }^{a, b)}$ \\
\hline & & & & & & & QIMDSWTLOTGYPVLNVIR ${ }^{\mathrm{a})}$ & NMDDKVNGYENIK ${ }^{\mathrm{b})}$ \\
\hline & & & & & & & YETIPTLNR ${ }^{b /}$ & FQNLVISNACEYOTK ${ }^{\mathrm{b})}$ \\
\hline & & & & & & & YYEDYFDEK $^{\mathrm{b})}$ & AFPCLDEPGYK ${ }^{\mathrm{b})}$ \\
\hline & & & & & & & YPIYIQAIK ${ }^{\mathrm{b})}$ & FSNAEODDLWCSLTEEAHR ${ }^{\mathrm{b})}$ \\
\hline & & & & & & & $\begin{array}{l}\text { NWMGIICTLNDPTKYE- } \\
\text { TIPTLNR }^{\text {b) }}\end{array}$ & $\begin{array}{l}\text { PLSVAIGKPDEIA- } \\
\text { PISGDPITFAK }\end{array}$ \\
\hline & & & & & & & LVIHDLAHOWFGNLVTMK $^{\text {b) }}$ & QDYSLSEYVSDIASOMK ${ }^{\mathrm{b})}$ \\
\hline & & & & & & & NFLLVLDPDSLOSAR ${ }^{\mathrm{b})}$ & \\
\hline \multirow[t]{8}{*}{502} & EQ111274 & $3.3 \mathrm{E}-13$ & 220.3 & $4.6 \mathrm{E}-12$ & 150.3 & $156 / 148$ & TYYESTVTSTSTTK ${ }^{a, b)}$ & DVNPDWSTYDKAYNDIK ${ }^{\mathrm{b})}$ \\
\hline & & & & & & & SISTDCGST- & YAIFNVGSEK ${ }^{\mathrm{a}, \mathrm{b})}$ \\
\hline & & & & & & & VTSSSTSTTTTSTVIIDK ${ }^{a, b)}$ & \\
\hline & & & & & & & IPSODTMNSITQEMLR ${ }^{\mathrm{a}, \mathrm{b})}$ & EYTVAVIGADDCWK ${ }^{\mathrm{a}, \mathrm{b})}$ \\
\hline & & & & & & & SMTQELLQCGYNPNYLIK ${ }^{\mathrm{a}, \mathrm{b})}$ & $\begin{array}{l}\text { AFSGNYYMTQATPCS- } \\
\text { FYDTPK }^{\mathrm{a}, \mathrm{b})}\end{array}$ \\
\hline & & & & & & & ERIPSODTMNSITQEMLR ${ }^{\mathrm{a}, \mathrm{b})}$ & NQIIASIIGYKa) \\
\hline & & & & & & & YPFIDKDLFR $^{\mathrm{a}, \mathrm{b})}$ & $\begin{array}{l}\text { TIEEVFTFDK- } \\
\text { TYYESTVTSTSTTK }{ }^{\text {b) }}\end{array}$ \\
\hline & & & & & & & TIEEVFTFDK ${ }^{a)}$ & \\
\hline \multirow[t]{4}{*}{11704} & EQ122476 & 8.3E-11 & 40.2 & $2.6 \mathrm{E}-7$ & 60.2 & $116 / 110$ & TEEDFDPGSK ${ }^{\mathrm{a}, \mathrm{b})}$ & TGEYIGWETNKK ${ }^{a, b)}$ \\
\hline & & & & & & & SCEADINYLYK ${ }^{\mathrm{a}, \mathrm{b})}$ & TEEDFDPGSKFHIVADVPYIR $^{\mathrm{a})}$ \\
\hline & & & & & & & TGEYIGWETNK ${ }^{\mathrm{b})}$ & GITTEDQYNCDWWK ${ }^{\text {b) }}$ \\
\hline & & & & & & & FHIVADVPYIR $^{\mathrm{a}, \mathrm{b})}$ & \\
\hline \multirow[t]{3}{*}{9015} & EQ119787 & $7.4 \mathrm{E}-9$ & 20.2 & $1.0 \mathrm{E}-8$ & 78.26 & 53 & YDVOSTPNSIK ${ }^{\mathrm{b})}$ & GNMMDSSTELISLDPK ${ }^{\mathrm{b})}$ \\
\hline & & & & & & & NECACSSSFIGFK ${ }^{\mathrm{b})}$ & FALEQDSGIIVK ${ }^{\mathrm{b})}$ \\
\hline & & & & & & & LVTDLNKPVIVTLSR $^{\mathrm{a}, \mathrm{b})}$ & GNMMDSSTELISLDPK ${ }^{\mathrm{a}, \mathrm{b})}$ \\
\hline \multirow[t]{3}{*}{10164} & EQ120936 & 4.1E-14 & 40.2 & 1.7E-12 & 60.3 & 156 & KGLTSISNMK ${ }^{\mathrm{a}, \mathrm{b})}$ & YYEDYFDEK $^{\mathrm{a})}$ \\
\hline & & & & & & & AFPCFDEPEYK ${ }^{a)}$ & FSNAEODDLWSSLTEEAHR ${ }^{a, b)}$ \\
\hline & & & & & & & QIMDTWTLQTGYPVLNVVR & \\
\hline \multirow[t]{3}{*}{2506} & EQ113278 & $1.5 \mathrm{E}-10$ & 58.3 & - & - & - & EYFAGKVDYSAVER $^{\text {a) }}$ & $\begin{array}{l}\text { YIWATNEFEPTVNYOT- } \\
\text { ADPQK }^{\text {a) }}\end{array}$ \\
\hline & & & & & & & ALLEYSNNSPVITVDDDIPIDR ${ }^{a)}$ & $\begin{array}{l}\text { VKASLYDLGEI- } \\
\text { GMNLMDDSOTLNDMOR }^{\text {a) }}\end{array}$ \\
\hline & & & & & & & SVYTLNQALANIIAAAR ${ }^{\mathrm{a})}$ & \\
\hline \multirow[t]{3}{*}{2546} & EQ113318 & $1.9 \mathrm{E}-06$ & 28.2 & $3.4 \mathrm{E}-07$ & 28.2 & 148 & DMLSCVYSK ${ }^{a, b)}$ & YLNWSLDESIIPR ${ }^{\mathrm{a}, \mathrm{b})}$ \\
\hline & & & & & & & SSSYFKEPNSVINQITETIKK ${ }^{\mathrm{a})}$ & EPNSVINQITETIK ${ }^{\mathrm{b})}$ \\
\hline & & & & & & & YGGEEEWNFLWKR ${ }^{\text {b) }}$ & \\
\hline \multirow[t]{2}{*}{9110} & EQ119882 & 1.1E-12 & 10.6 & $7.2 \mathrm{E}-13$ & 30.3 & & EPDLVINOITETITK ${ }^{\mathrm{b})}$ & YLNWSLDESIIPK ${ }^{\mathrm{b})}$ \\
\hline & & & & & & & YFKEPDLVINQITETITKKa,b) & \\
\hline \multirow[t]{2}{*}{6515} & EQ117287 & $2.6 \mathrm{E}-10$ & 30.8 & $2.4 \mathrm{E}-05$ & 10.2 & 66 & SKDPLASPK ${ }^{\mathrm{a})}$ & IIANYLSDQEEIDTMVR ${ }^{\text {a) }}$ \\
\hline & & & & & & & NRPIEDIVAESOK ${ }^{\mathrm{a})}$ & SVGYAMSDSTTR $^{\text {b) }}$ \\
\hline \multirow[t]{2}{*}{12004} & EQ122776 & $1.6 \mathrm{E}-05$ & 30.2 & 1.1E-06 & 20.34 & 66 & LSNCADYIWDTR $^{\text {b) }}$ & SNDDLEYPDVOILK ${ }^{\mathrm{a}, \mathrm{b})}$ \\
\hline & & & & & & & STEDIINESKDFLQR ${ }^{\mathrm{a})}$ & TKYDWAFLSEKNPLLFK ${ }^{\mathrm{a})}$ \\
\hline \multirow[t]{2}{*}{5522} & EQ116294 & $1.6 \mathrm{E}-05$ & 20.2 & $2.9 \mathrm{E}-05$ & 30.2 & $116 / 110$ & $\begin{array}{l}\text { NPSSOPLHECDIYOSTNAG- } \\
\text { NAFK }\end{array}$ & LMSVLGTDALPEDK $^{\mathrm{a}, \mathrm{b})}$ \\
\hline & & & & & & & GITTEDOYNCDWWK ${ }^{\mathrm{b})}$ & YPWTTYKNPNIKR ${ }^{\text {a) }}$ \\
\hline 11529 & EQ122301 & $4.8 \mathrm{E}-9$ & 10.1 & $2.2 \mathrm{E}-08$ & 20.2 & 43 & LIDETPGNR $^{\mathrm{b})}$ & VTNTGSTGFEGVSAK ${ }^{a, b)}$ \\
\hline 13504 & EQ124276 & - & - & $6.8 \mathrm{E}-07$ & 20.18 & 53 & SLVEANKPVYTR ${ }^{\mathrm{b})}$ & TLIEANKPVYTR $^{\mathrm{b})}$ \\
\hline
\end{tabular}

a) Peptide tags identified from in-solution sample.

b) Peptide tags identified from in-gel samples. Peptide tags in bold were identified in the search of MS/MS data against the EST database.

c) The 1-DE fraction comprising the highest abundance of peptide tags for a matched scaffold. 
predicted peptide sequence from scaffolds 128, 2546, 10164 , the APG01291 and APG08296 EST clusters indicated homology to M1 zinc metalloproteases in insect species such as Nasonia vitripennis (XM001608158), Aedes aegypti (XM001662276), Culex pipiens (XM001865762) and T. castaneum (XM963778) (Table 3) in addition to membrane alanyl aminopeptidases found in D. melanogaster (NM143431). InterProScans of all sequences confirmed motifs characteristic of a zinc-dependant M1 metalloprotease (PTHR11533/ IPR001930) in addition to identifying a signal-peptide sequence at codon positions 1-24 and a trans-membrane domain at residues 5-23 on the predicted sequence for scaffold 128. A signal peptide sequence and trans-membrane domain were also detected on the predicted amino acid sequence from APG01291 at codon positions 1-54 and 1053, respectively.

TBLASTN searches of the predicted amino acid sequences from scaffolds 6515 and 12004 and EST cluster APG28784 indicated homology to glucose dehydrogenases found in A. aegypti (XM001648246), D. melanogaster (NM058155) and N. vitripennis (XM001600369) and alcohol and choline dehydrogenases found in $C$. pipiens (XM001843213 and XM001848802, respectively). APG28784 and sequence from scaffold 6515 matched to XM001946910 (ACYPI000113) and matched sequence from scaffold 12004 matched to XM001952558 (ACYPI005582). InterProScans of the predicted amino acid sequences indicated motifs matching to glucose-methanol-choline oxidoreductases (IPR000172 N-terminal and IPR007867 C-terminal; PTHR11552).
Two peptide tags matching to EST cluster APG10010 and Scaffold11529 (corresponding to XM001951513; ACYPI003308) were detected. The BLAST search results (Table 3 ) of the consensus EST sequence indicated homology to members of the SGL family (pfam08450), including regucalcin and anterior fat body proteins in various insects, such as A. aegypti (XM001650960), C. pipiens (XM001848416) and D. melanogaster (BAA92938). InterProScans of the predicted ORF identified motifs matching to senescence marker proteins (IPR005511) and regucalcin (IPR008367).

\subsubsection{Unidentified proteins}

No identity could be assigned to five of the matched EST clusters and predicted peptide sequences deduced from genomic scaffolds. Of these, APG02147 and the corresponding genomic sequence on scaffold 502, both matching to XM001943863 (ACYPI009881), were extremely well represented in both the in-solution and ingel samples. The predicted protein comprises 1161 amino acid residues with a predicted molecular mass of $130 \mathrm{kDa}$ coded by a gene organized into 26 exons (Fig. 2). The protein sequence yielded no homologues in BLAST searches against the NCBI non-redundant database, no identity or function by InterProScan motif searches, and no predicted structural folds by the Protein Structure Prediction Meta Server (www.Pcons.net). By InterProScan, however, a putative signal peptide was identi-

Table 3. BLAST matches and InterProScan search results of the predicted amino acid sequences determined from EST and corresponding genomic sequences

\begin{tabular}{|c|c|c|c|c|c|c|c|}
\hline \multirow{2}{*}{$\begin{array}{l}\text { Protein } \\
\text { identification } \\
\text { Angiotensin } \\
\text { Converting Enzyme }\end{array}$} & \multirow{2}{*}{$\begin{array}{l}\text { EST cluster } \\
\text { or scaffold } \\
\text { Scaff11704 }\end{array}$} & \multirow{2}{*}{$\begin{array}{l}\begin{array}{l}\text { A. pisum } \\
\text { reference } \\
\text { sequence }\end{array} \\
\text { XM001951605 }\end{array}$} & \multirow{2}{*}{$\begin{array}{l}\text { NCBI accession } \\
\text { (Best Hit) } \\
\text { AY487174 }\end{array}$} & \multirow{2}{*}{$\begin{array}{l}\text { Organism } \\
\text { Locusta migratoria }\end{array}$} & \multicolumn{2}{|c|}{$\begin{array}{l}\text { TBLASTN } \\
\text { E-value score }\end{array}$} & \multirow{2}{*}{$\begin{array}{l}\text { InterPro ID } \\
\text { IPR001548 }\end{array}$} \\
\hline & & & & & $8 e-66$ & 256 & \\
\hline & APG09617 & XM001951605 & AY487174 & Locusta migratoria & $6 e-59$ & 231 & IPR001548 \\
\hline & APG10189 & XM001944530 & AY487174 & Locusta migratoria & $4 e-49$ & 197 & IPR001548 \\
\hline & Scaff5522 & XM001944530 & AY487174 & Locusta migratoria & $2 e-41$ & 174 & IPR001548 \\
\hline & APG09831 & XM001944530 & AY487174 & Locusta migratoria & $1 e-65$ & 256 & IPR001548 \\
\hline \multirow{3}{*}{$\begin{array}{l}\text { M1 zinc } \\
\quad \text { metalloprotease }\end{array}$} & APG01291 & XM001950011 & XP001662326 & Aedes aegypti & $3 e-52$ & 208 & IPR001930 \\
\hline & Scaff10164 & XM001950011 & XM001608158 & Nasonia vitripennis & 0.0 & 826 & IPR001930 \\
\hline & Scaff128 & XM001948813 & XM963778 & Tribolium castaneum & $2 e-96$ & 359 & IPR001930 \\
\hline \multirow[t]{3}{*}{$\begin{array}{l}\text { GMC } \\
\quad \text { oxidoreductase }\end{array}$} & APG28784 & XM001946910 & XP001648296 & Aedes aegypti & $9 e-64$ & 250 & $\begin{array}{l}\text { IPR000172/ } \\
\text { IPR007867 }\end{array}$ \\
\hline & Scaff6515 & XM001946910 & XM001648246 & Aedes aegypti & $4 e-106$ & 389 & $\begin{array}{l}\text { IPR000172/ } \\
\text { IPR007867 }\end{array}$ \\
\hline & Scaff12004 & XM001952558 & XM310335 & Anopheles gambiae & $2 e-102$ & 379 & IPR000172 \\
\hline \multirow[t]{2}{*}{$\begin{array}{l}\text { SMP-30 } \\
\quad \text { (Regucalcin) }\end{array}$} & APG10010 & XM001951513 & XM001650960 & Aedes aegypti & $6 e-60$ & 236 & $\begin{array}{l}\text { IPR005511/ } \\
\text { IPR008367 }\end{array}$ \\
\hline & Scaff11529 & XM001951513 & NM169602 & $\begin{array}{l}\text { Drosophila } \\
\quad \text { melanogaster }\end{array}$ & $5 e-46$ & 191 & $\begin{array}{l}\text { IPR005511/ } \\
\text { IPR008367 }\end{array}$ \\
\hline
\end{tabular}






Figure 2. Nucleotide sequence of ACYPI009881 from A. pisum and its predicted amino acid sequence. The predicted signal peptide is underlined. Peptides identified by MS are in bold and intron/exon boundaries are denoted by a vertical line. All introns follow the GT/AG rule.

fied at residues 1-16 and a cleavage site at residue 16. Taken together, these data indicate that ACYPI009881 represents a novel gene.

Two other unidentified proteins were recovered from the in-solution sample, matching to clusters APG11079 and APG01142, which were both located along Scaffold 2506 of the aphid genome and match to XM001951836 (ACYPI008224) and XM001951823 (ACYPI006346), respectively. Of the six peptides matched to Scaffold 2506, three are shared with APG11079 and three are shared with cluster APG01142. Approximately $3.5 \mathrm{~kb}$ separate both loci along the genomic scaffold, indicating that they are either representatives of a single gene or independent genes located along the same scaffold. InterProScans of the predicted amino acid sequence for APG11079 and APG01142 yielded no significant hits. Signal peptides were calculated at positions 1-28 for APG11079 and positions 1-20 for APG01142 when sequences beginning at the putative start codons were searched. The predicted amino acid sequences from scaffolds 13 504, 9110 and 9015 yielded no significant matches from BLAST searches.

\section{Discussion}

The major proteins in the saliva of pea aphids were identified and characterised using the complementary MS methods of LC-MS/MS on unseparated salivary concentrates (in-solution samples) and GE-LC-MS/MS on tryptic peptides obtained from 1-DE separated salivary proteins (in-gel samples). In total, 60 and 70 well-supported peptides were obtained in searches against the pea aphid EST and genomic databases, respectively. The number of peptides would have been greater if the stringent post processing filters used with TurboSEQUEST had been relaxed and if all proteins with singlepeptide hits had been reported. These peptides could be assigned to 10 EST clusters and at least 13 genomic scaffolds. It is difficult to obtain the precise number of matched genomic scaffolds because gene duplications, pseudogenes, gene families etc. can inflate the number of genomic regions, yielding the same or similar tryptic peptides. Importantly, all the matched ESTs or genomic hits present in the cumulative in-gel digested samples were present in the in-solution digested samples. This overlap provides some validation of the identified proteins. Differences between the identified proteins obtained from different preparative samples are often reported, e.g. [24], highlighting the importance of adopting multiple approaches to characterise and identify novel sets of proteins, as used here. The failure to match MS/ MS reads against proteins deposited in the NCBI nr database indicates that the proteins reported during this study were of aphid origin and were not derived from microbial contamination.

The most abundant protein (in terms of overall number of matched peptide tags) in pea aphid saliva was represented by the EST cluster APG02147 (ACYPI009881). No functional motifs, homologues or putative structural folding were identified after BLAST searches, InterProScans and protein structure prediction software. The protein comprises two large, imperfect, repeated domains of 439 and 432 residues respectively, and the polypeptide sequence has an excess of serine $(11.4 \%)$, tyrosine $(7.1 \%)$ and cysteine $(4.2 \%)$ residues, relative to their contribution to total aphid protein $(4.6,1.1$ and $1.7 \%$, respectively). The abundance and amino-acid composition of the protein are suggestive of its contribution to the gelling saliva, which solidifies to form a sheath on extrusion from the aphid stylets [25], partly because the sulphydryl groups on the cysteine residues are oxidized to form disulphide bonds. 
Sequences with close similarity to ACYPI009881 are also present in the $M$. persicae EST database (EST accessions EC387934, EC388457 and EE572212 in NCBI) and in the insolution digested salivary proteins of $M$. persicae [14]. These data indicate that ACYPI009881 is not specific to the pea aphid, consistent with its putative role as a sheath protein. The salivary sheath is believed to contribute to the molecular concealment of feeding aphids from plant defences, including preventing leakage of sieve element contents into the apoplast, a known trigger of plant defences [10, 26, 27].

Two members of the metalloprotease family were identified within aphid saliva. The first was matched to ACE (peptidyl dipeptidase A, EC 3.4.15.1), a member of the M2metallopeptidase family, and was demonstrated in the in-solution digested sample and in the 110- and 100-kDa bands of the 1-DE secreted saliva. ACE have been described as nonspecific dipeptydyl carboxypeptidases [28] and have been characterised in a number of insects, including Bombyx mori, D. melanogaster, L. migratoria, Musca domestica, and S. littoralis [29-33]. In insects, ACE are thought to be involved in regulating peptide hormones and neuropeptides by removing dipeptides, dipeptideamides and tripeptideamides from the $\mathrm{C}$ terminus of short peptides $([31,32,34,35]$, reviewed in [36]). The matched protein identified here from pea aphid saliva is homologous to Drosophila ACE (Ance; AAF53353). Transcripts of ACE-like homologs have been identified in EST libraries generated from salivary glands of the sand fly Lutzomyia longipalpis [37] and pea aphid (www.aphidests.org). A non-salivary gland origin for salivary ACE must also be considered. ACE is a major circulating peptidase, abundant in the haemolymph of various insects $[32,33]$ and the high levels of Ance-like transcript demonstrated in the haemolymph of the lepidopteran S. littoralis lead the authors to conclude that the fat body was the probable source [33].

The second type of metalloprotease identified in pea aphid saliva is homologous to the M1-type zinc-dependant metalloprotease, and was demonstrated in the in-solution digested samples and the 156- and 148-kDa bands of the 1DE gels. Peptides matching to four loci on the pea aphid genome and a single EST (APG01291) demonstrated homology to this family of proteins. M1 metalloproteases cleave singleamino acids from the $\mathrm{N}$ terminus of small peptides and secreted metalloproteases have been identified in the salivary glands of Anopheles mosquito and the tick Ixodes ricinus [38, 39], and in the saliva of the tick I. scapularis [40]. To date, proteases have not been demonstrated in aphid saliva using substrate-specific assays or zymography [16]. The discrepancy between these data and the proteomic analysis here may be explained by the low activity of the enzymes in isolated saliva, perhaps because of the lack of specific cofactors. These limitations are not present when using proteomic and MSy technologies, although the biological action of the metalloproteases identified by proteomics remains to be determined. Plant phloem sap contains a wide diversity of proteins [41], albeit generally at low concentrations, and some may play a role in plant defence against phloem feeders. The degradation of phloem proteins by aphid salivary peptidases may both suppress plant defence responses and provide a supplementary source of nitrogen to the aphid by increasing/recycling available free amino acids.

Of all the enzyme activities associated with or predicted for aphid saliva, oxidases are the most frequently reported (reviewed in [9]), and an oxidase-like protein was identified in this study. Although BLAST searches indicated homology to glucose, alcohol and choline dehydrogenases from a number of different insect species, it is prudent to classify this protein based on family (i.e. as GMC-oxidoreductase) until the specific function and identity of this protein has been determined experimentally. GMC-oxidoreductases are a large family of flavin-adenin-dinucleotide (FAD) flavoproteins [42], which catalyze the removal of hydrogen atoms, and electrons from the compounds on which they act. Oxidoreductase activity has been demonstrated using substrate-specific assays in the saliva of the spotted alfalfa aphid Therioaphis maculata and A. pisum [15] and glucose oxidase has been identified in the saliva of Megoura viciae [14]. Insect GMC-oxidoreductases have been implicated previously in modifying plant defences. For example, the salivary glucose oxidase of Helicoverpa $z e a$ reduces the nicotine defence pathway in tobacco plants [43] and suppresses jasmonic acid related plant defence pathways [44]. More generally, oxidoreductase activity could also detoxify noxious phytochemicals, and promote gelling of the sheath saliva by enhancing disulphide bridge formation $[19,45]$.

A calcium-binding protein has long been predicted in aphid saliva, as the mechanism by which aphids suppress occlusion of the sieve elements from which they feed [10, 27]. Sieve element occlusion mechanisms include the release of phloem proteins, which form aggregates that seal up the sieve element when wounded [46-49]. Calcium has been demonstrated to be an important mediator for sieve element occlusion mechanisms and $\mathrm{Ca}^{2+}$ chelators such as EDTA have been demonstrated to reverse or prevent sieve tube occlusion [48]. Will et al. [10] demonstrated the reversal of sieve element occlusion forisomes in $\mathrm{V}$. faba in the presence of saliva concentrates of $M$. vicia associated with a conformational change in 40- and 43-kDa proteins when incubated with free calcium in a 2-D SDS-PAGE gel format. The $43-\mathrm{kDa}$ protein identified in the current study from pea aphid saliva (Fig. 1) is a strong candidate for this protein. It is a member of the SMP-30 family that includes proteins such as anterior fat body proteins and regucalcin. These proteins are $\mathrm{Ca}^{2+}$-binding proteins with multifunctional roles in the regulation of intracellular $\mathrm{Ca}^{2+}$ homeostasis and regulation of intracellular signalling [50-52].

This proteomics analysis coupled with EST and genomic sequence data of the pea aphid has yielded a candidate molecular basis for the key biological functions of aphid saliva. It should be noted that the salivary proteins reported here were obtained from artificial diets and confirmation of similar saliva composition during feeding from plants has yet to 
be determined. However, the proteins identified in this study allow future in planta validation of the role of saliva in aphidplant interactions. Hypotheses on the function of aphid saliva can now be couched in molecular terms. The specific hypotheses arising from this study are that (i) the metalloproteases degrade plant defensive proteins/peptides; (ii) the regucalcin inhibits calcium-mediated plugging of sieve elements; (iii) ACYPI009881 is a major component of the salivary sheath affording the stylets protection and a degree of concealment during probing and feeding phases; and (iv) the oxidoreductase promotes gelling of the sheath.

The data obtained here do not match the protein profiles in published studies of the saliva from different aphid species. Ongoing research of multiple aphid species indicates that this variation has a biological basis and is not an artefact of different experimental protocols. This variation is predicted to reflect differences in the biological activity of aphids with different plant ranges against the defences of different plant species. It has potential for both understanding the molecular basis of insect-plant interactions and the discovery of novel bioactive compounds with application in crop protection and beyond.

Access to and use of instrumentation of the UCD Conway Mass Spectrometry Resource (MSR) is gratefully acknowledged. We also thank C. Scaife and the staff at the MSR and Proteome Research Centre, UCD Conway Institute of Biomedical Research for support and advice with proteomic analysis, Dr Carlos Martinex-Fleites (Structural Biology Laboratory, York) for bioinformatics support and advice and Dr. Jules Westbrook for the critical appraisal of the manuscript. This research was funded by Science Foundation Ireland grant 03/IN3/B381 (to TLW) and Research Fellowship BB/C520898 (to AED).

The authors have declared no conflict of interest.

\section{References}

[1] Valenzuela, J. G., Exploring tick saliva: from biochemistry to 'sialomes' and functional genomics. Parasitology 2004, 129, S83-S94.

[2] Hovius, J. W. R., Levi, M., Fikrig, E., Salivating for knowledge: potential pharmacological agents in tick saliva. PLoS Med. 2008,5 , e43.

[3] Ribeiro, J. M., Nussenzveig, R. H., The salivary catechol oxidase/peroxidase activities of the mosquito Anopheles albimanus. J. Exp. Biol. 1993, 179, 273-287.

[4] Ribeiro, J. M., Francischetti, I. M., Role of arthropod saliva in blood feeding: sialome and post-sialome perspectives. Annu. Rev. Entomol. 2003, 48, 73-88.

[5] Calvo, E., Tokumasu, F., Marinotti, O., Villeval, J.-L. et al., Aegyptin, a novel mosquito salivary gland protein, specifically binds to collagen and prevents its interaction with platelet glycoprotein $\mathrm{VI}$, integrin \{alpha\}2beta 1, and von Willebrand factor. J. Biol. Chem. 2007, 282, 26928-26938.
[6] Korth, K. L., Dixon, R. A., Evidence for chewing insect-specific molecular events distinct from a general wound response in leaves. Plant Physiol. 1997, 115, 1299-1305.

[7] Lawrence, S. D., Novak, N. G., Maize genes induced by herbivory and volicitin. J. Chem. Ecol. 2004, 30, 2543-2557.

[8] Howe, G. A., Jander, G., Plant Immunity to Insect Herbivores. Annu. Rev. Plant Biol. 2008, 59, 41-66.

[9] Miles, P. W., Aphid Saliva. Biol. Rev. Camb. Philos. Soc. 1999, $74,41-85$.

[10] Will, T., Tjallingii, W. F., Thonnessen, A., van Bel, A. J. E., Molecular sabotage of plant defense by aphid saliva. Proc. Natl. Acad. Sci. USA 2007, 104, 10536-10541.

[11] Figueroa, C. C., Prunier-Leterme, N., Rispe, C., Sepúlveda, F. et al., Annotated expressed sequence tags and xenobiotic detoxification in the aphid Myzus persicae (Sulzer). Insect Sci. 2007, 14, 29-45.

[12] Sabater-Munozb, B., Legeai, F., Rispe, C., Bonhomme, J. et al., Large-scale gene discovery in the pea aphid Acyrthosiphon pisum (Hemiptera). Genome Biol. 2006, 7:R21.

[13] Mutti, N. S., Park, Y., Reese, J. C., Reeck, G. R., RNAi knockout of a salivary transcript leading to lethality in the pea aphid, Acyrthosiphon pisum. J. Insect Sci. 2006, 6, 38.

[14] Harmel, N., Létocart, E., Cherqui, A., Giordanengo, P. et al., Identification of aphid salivary proteins: a proteomic investigation of Myzus persicae. Insect Mol Biol. 2008, 17, 165174.

[15] Madhusudhan, V. V., Miles, P. W., Mobility of salivary components as a possible reason for differences in response of alfalfa to the spotted alfalfa aphid and pea aphid. Entomol. Exp. Appl. 1998, 86, 25-39.

[16] Cherqui, A., Tjallingii, W. F., Salivary proteins of aphids: a pilot study on identification, separation and immunolocalisation. J. Insect Physiol. 2000, 46, 1177-1186.

[17] Habibi, J., Backus, E. A., Coudron, T. A., Brandt, S. L., Effect of different host substrates on hemipteran salivary protein profiles Entomol. Exp. Appl. 2001, 98, 369-375.

[18] Rahbé, Y., Febvay, G., Protein toxicity to aphids - an in vitro test on Acyrthosiphon pisum. Entomol. Exp. Appl. 1993, 67, 149-160.

[19] Douglas, A. E., Price, D. R. G., Minto, L. B., Jones, E. et al., Sweet problems: insect traits defining the limits to dietary sugar utilisation by the pea aphid, Acyrthosiphon pisum. J. Exp. Biol. 2006, 209, 1395-1403.

[20] Yan, J. X., Wait, R., Berkelman, T., Harry, R. A, Westbrook, J. A. et al., A modified silver staining protocol for visualization of proteins compatible with matrix-assisted laser desorption/ionization and electrospray ionization-mass spectrometry. Electrophoresis 2000, 17, 3666-3672.

[21] Eng, J. K., McCormack, A. L., Yates, J. R. III, An approach to correlate MS/MS data to amino acid sequences in protein database. J. Am. Soc. Mass Spectrom. 1994, 5, 976-989.

[22] Huang, X., Madan, A., CAP3: A DNA sequence assembly program. Genome Res. 1999, 9, 868-877.

[23] Burge, C. B., Karlin, S., Finding the genes in genomic DNA. Curr. Opin. Struct. Biol. 1998, 8, 346-354.

[24] Kalume, D. E., Okulate, M., Zhong, J., Reddy, R. et al., A proteomic analysis of salivary glands of female Anopheles gambiae mosquito. Proteomics 2005, 5, 3765-3777. 
[25] McLean, D. L., Kinsey, M. G., Identification of electrically recorded curve patterns associated with aphid salivation and ingestion. Nature 1965, 205, 1130-1131.

[26] Tjallingii, W. F., Salivary secretions by aphids interacting with proteins of phloem wound responses. J. Exp. Bot. 2006, 57, 739-745.

[27] Will, T., van Bel, A. J. E., Physical and chemical interactions between aphids and plants. J. Exp. Bot. 2006, 57, 729-737.

[28] Corvol, P., Williams, T. A., Soubrier, F., Peptidyl dipeptidase A: angiotensin I-converting enzyme. Methods Enzymol. 1995, 248, 283-305.

[29] Quan, G. X., Mita, K., Okano, K., Shimada, T. et al., Isolation and expression of the ecdysteroid-inducible angiotensinconverting enzyme-related gene in wing discs of Bombyx mori. Insect Biochem. Mol. Biol. 2001, 31, 97-103.

[30] Siviter, R. J., Taylor, C. A. M., Cotta, D. M., Denton, A. et al., Ance, a Drosophila angiotensin-converting enzyme homologue, is expressed in imaginal cells during metamorphosis and is regulated by the steroid, 20-hydroxyecdysone. Biochem. J. 2002, 367, 187-193.

[31] Isaac, R., Schoofs, L., Williams, T. A., Veelaert, D. et al., A novel activity of insect peptidyl-dipeptidase $A$ (angiotensin I-converting enzyme): the hydrolysis of lysyl-arginine and arginyl-arginine from the C-terminus of an insect prohormone peptide. Biochem. J. 1998, 330, 61-65.

[32] Lamango, N. S., Nachman, R. J., Hayes, T. K., Strey, A., Isaac, R. E., Hydrolysis of insect neuropeptides by an angiotensinconverting enzyme from the housefly, Musca domestica. Peptides 1997, 18, 47-52.

[33] Lemeire, E., Vanholme, B., Van Leeuwen, T., Van Camp, J., Smagghe, G., Angiotensin-converting enzyme in Spodoptera littoralis: molecular characterization, expression and activity profile during development. Insect Biochem. Mol. Biol. 2008, 38,166-175.

[34] Kim, H. M., Shin, D. R., Yoo, O. J., Lee, H., Lee, J. O., Crystal structure of Drosophila angiotensin I-converting enzyme bound to captopril and lisinopril. FEBS Lett. 2003, 538, 6570.

[35] Schoofs, L., Veelaert, D., De Loof, A., Huybrechts, R., Isaac, E., Immunocytochemical distribution of angiotensin I-converting enzyme like immunoreactivity in the brain and testis of insects. Brain Res. 1998, 785, 215-227.

[36] Macours, N., Hens, K., Zinc-metalloproteases in insects: ACE and ECE. Insect Biochem. Mol. Biol. 2004, 34, 501-510.

[37] Valenzuela, J. G., Garfield, M., Rowton, E. D., Pham, V. M., Identification of the most abundant secreted proteins from the salivary glands of the sand fly Lutzomyia longipalpis, vector of Leishmania chagasi. J. Exp. Biol. 2004, 207, 37173729.

[38] Arca, B., Lombardo, F., Valenzuela, J. G., Francischetti, I. M. et al., An updated catalogue of salivary gland transcripts in the adult female mosquito, Anopheles gambiae. J. Exp. Biol. 2005, 208, 3971-3986.

[39] Decrem, Y., Beaufays, J., Blasioli, V., Lahaye, K. et al., A family of putative metalloproteases in the salivary glands of the tick Ixodes ricinus. FEBS J. 2008, 275, 1485-1499.

[40] Francischetti, I. M., Mather, T. N., Ribeiro, J. M., Cloning of a salivary gland metalloprotease and characterization of gelatinase and fibrin(ogin)lytic activities in the saliva of the Lyme disease tick vector Ixodes scapularis. Biochem. Biophys. Res. Commun. 2003, 305, 869-875.

[41] Kehr, J., Phloem sap proteins: their identities and potential roles in the interactions between plants and phloem-feeding insects. J. Exp. Bot. 2006, 57, 767-774.

[42] Cavener, D. R., GMC oxidoreductases. A newly defined family of homologous proteins with diverse catalytic activities. J. Mol. Biol. 1992, 223, 811-814.

[43] Eichenseer, H., Mathews, M. C., Bi, J. L., Murphy, J. B., Felton, G. W., Salivary glucose oxidase: multifunctional roles for Helicoverpa zea? Arch. Insect Biochem. Physiol. 1999, 42, 99-109.

[44] Musser, R. O., Hum-Musser, S. M., Eichenseer, H., Peiffer, M. et al., Caterpillar saliva beats plant defenses. Nature 2002, 416, 599-600.

[45] Miles, P. W., Oertli, J. J., The significance of antioxidants in the aphid-plant interaction: the redox hypothesis. Entomol. Exp. Appl. 1993, 67, 285-273.

[46] King, R. W., Zeevaart, J. A., Enhancement of phloem exudation from cut petioles by chelating-agents. Plant Physiol. 1974, 53, 96-103.

[47] Knoblauch, M., van Bel, A. J. E., Sieve tubes in action. The Plant Cell 1998, 10, 35-50.

[48] Knoblauch, M., Peters, S. W., Ehlers, K., van Bel, A. J. E., Reversible calcium-regulated stopcocks in legume sieve tubes. The Plant Cell 2001, 13, 1221-1230.

[49] Knoblauch, M., Noll, G. A., Mueller, T., Pruefer, D. et al., ATPindependent contractile proteins from plants. Nat. Mats. 2003, 2, 600-603.

[50] Goto, S. G., Expression of Drosophila homologue of senescence marker protein-30 during cold acclimation. J. Insect Physiol. 2000, 46, 1111-1120.

[51] Yamaguchi, M., Role of regucalcin in maintaining cell homeostasis and function. Int. J. Mol. Med. 2005, 15, 371389.

[52] Nikapitiya, C., De Zoysa, M., Kang, H. S., Oh, C., Whang, I., Lee, J., Molecular characterization and expression analysis of regucalcin in disk abalone (Haliotis discus discus): Intramuscular calcium administration stimulates the regucalcin mRNA expression. Comp. Biochem. Physiol. B Biochem Mol. Biol. 2008, 150, 117-124. 